\title{
138. 青色LEDにYAG蛍光体を組み合わせた光源体の検討
}

\section{山田 健一 村井 卓生 今井 康雄 石井 健一 （三菱電機照明株式会社）}

\section{1. 緒 言}

近年, 高輝度青色発光ダイオード(LED : Light Emitting Diode)が開発され，光産業界のみならず 照明業界においても注目が集まっている。なかでも青色 $\mathrm{LED} に \mathrm{YAG}\left(\mathrm{Y}_{3} \mathrm{Al}_{5} \mathrm{O}_{12}\right.$ : Gd,Ce)蛍光体を組 み合わせた白色 LED は, 1996 年の発売以来, その発光効率が年々向上しており, 特に小型, 省エネ, 長寿命，水銀レスといった面から照明用新光源としての期待度が大きい。このような背景から, LED 光源は足元灯などの用途から照明分野に徐々に浸透してきている。しかしながら，一般照明用光源を 目的とした場合, LED は素子 1 個あたりの光出力が弱く，また指向性が高いため，これをアレイ状あ るいはマトリックス状に集積し，かつ均斉度を持たせた光源体とする必要がある。そこで，本研究で は, 青色 LED にYAG 蛍光体膜を組み合わせた光源体を想定し, 反射型, 透過型の各形状における光 の諸特性について検討した。

\section{2. 実 験}

本実験は, 日亜化学工業製のチップ型青色 LED(NSCB100)及び化成オプトニクス製の YAG 蛍光体 (P46-Y3)を用いて行った。透過型光源体については, 径 $30 \mathrm{~mm}$ のガラスシャーレの底面に所定の膜 厚の YAG 蛍光体膜を形成し，青色 LED をシャーレ上部に設置した。そして，青色 LED を定格の順 方向電流 $20 \mathrm{~mA}$ で点灯させ, シャーレ下部からの透過光について調べた。反射型光源体については, アルミニウム $(\mathrm{Al})$ 及び硫酸バリウム $\left(\mathrm{BaSO}_{4}\right)$ の各反射膜を設けたシャーレ底面に同様に所定の膜厚の YAG 蛍光体膜を形成し, 青色 LED をシャーレ上部から点灯させ, その反射光について調べた。なお, 光特性の評価は輝度, 色度及び分光分布測定を行い検討した。

\section{3. 結 果}

まず，透過型及び反射型の各光源体の発光色について調べた結果，透過型の場合では YAG 蛍光体 膜厚に応じて青 $\rightarrow$ 白 $\rightarrow$ 黄と容易に色可変でき, $\mathrm{YAG}$ 蛍光体膜厚 $68 \mu \mathrm{m}$ において色度座標で $\mathrm{x}=0.32$, $\mathrm{y}=0.33$ を示す白色光が得られた。一方, 反射型の場合には $\mathrm{Al}$ 反射, $\mathrm{BaSO}_{4}$ 反射のいずれにおいても YAG 蛍光体膜厚により発光色が大きく変化せず，今 回検討した膜厚条件では青みの白色光が得られる程 度であった。

次に, YAG 蛍光体膜表面からの発光を完全拡散光 と仮定し, 輝度測定結果より各光源体の光束を求め検 討した。図に各光源体における YAG 蛍光体膜厚に対 しての全光束の比較を示す。これより，透過型よりも 反射型の形状において高い光束が得られることが明 らかである。さらに, 反射型の場合では反射膜に拡散 成分の高い $\mathrm{BaSO}_{4}$ を用いることで, 透過型と比較し て 2 倍以上の光束が得られることが確認された。そ れゆえ, 青色 LED に YAG 蛍光体を介して発光させ る光源体については,反射型形状を採用することが高 光束を実現するうえで有効であり，また，その際に拡 散成分の高い反射膜を設けることが望ましいと考え られる。

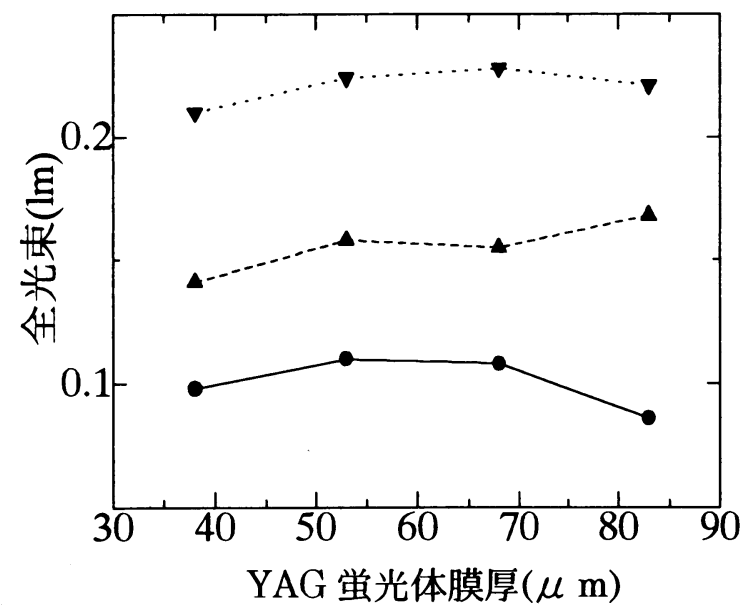

図各光源体の全光束比較

: 透過型, $\boldsymbol{\Delta}: \mathrm{Al}$ 反身型, $\boldsymbol{\nabla}: \mathrm{BaSO}_{4}$ 反射型

謝 辞 本研究は「高効率電光変換化合物半導体開発(21 世紀のあかり計画)」の一環として,財団法人 金 属系材料研究開発センターが新エネルギー・産業技術総合開発機構から委託を受けて行われたものである。

A Study of the Light Source Form Composed of Blue LED and YAG Phosphor

Kenichi YAMADA, Takuo MURAI, Yasuo IMAI, Kenichi ISHII 